\title{
Promoting Writing in Mathematics: Prospective Teachers' Experiences and Perspectives on the Process of Writing When Doing Mathematics as Problem Solving
}

AnA KuZle ${ }^{1}$

$\approx$ Despite a great deal of research on the benefits of writing in mathematics, writing plays a minimal role, if any, in secondary and tertiary mathematics education. In order for teachers to use writing in their classrooms, they themselves have to experience writing mathematics within the teacher education programme. The present paper reports on a study aimed at addressing this gap. In a problem-solving seminar, preservice teachers had an opportunity to experience writing in mathematics and report how this affected their problem-solving processes and shaped their attitudes towards incorporating writing in their classrooms. In order to provide a more detailed description of the phenomenon, four participants were chosen based on their beliefs about mathematics. All of the participants struggled with writing their explanations. Those who used writing as a method to support metacognitive processes while exploring mathematics tended to respond positively to the writing process. The others used writing merely as a method to produce a formal document to be evaluated by the instructor. Consequently, those who viewed writing and doing mathematics as an intertwined process expressed a positive attitude towards using writing in their mathematics classroom. This was, unfortunately, not the case when writing and doing mathematics were seen as two separate processes. Implications for teacher education programmes are presented at the end of the report.

Keywords: Attitudes; Beliefs; Metacognition; Problem solving; Prospective mathematics teachers; Writing in mathematics 


\section{Spodbujanje pisanja pri matematiki - izkušnje in pogledi bodočih učiteljev na proces pisanja pri reševanju problemov pri matematiki}

ANA KuzLE

$\propto$ Kljub številnim raziskavam o koristi pisanja pri matematiki ima ta dejavnost - če že - minimalno vlogo v sekundarnem in terciarnem izobraževanju. Da bi se učitelji posluževali pisanja pri učnih urah, morajo tudi sami dobiti izkušnjo pisanja pri matematiki, in sicer med svojim pedagoškim izobraževanjem. Članek poroča o raziskavi, ki je bila namenjena obravnavi te vrzeli. Na seminarju iz reševanja problemov so prihodnji učitelji dobili izkušnjo pisanja pri matematiki; poročali so, kako je to vplivalo na njihov proces reševanja problemov in oblikovalo njihov odnos do vključevanja pisanja $\mathrm{v}$ njihove učne ure. $\mathrm{Z}$ namenom podrobnejšega opisa pojava so bili glede na prepričanje o matematiki izbrani štirje udeleženci. Vsi so se spopadali s pisanjem svojih razlag. Tisti, ki so uporabili pisanje kot metodo za podporo metakognitivnih procesov pri raziskovanju matematike, so se nagibali k pozitivnemu odzivu do procesa pisanja. Preostali so uporabili pisanje samo kot metodo za oblikovanje pisnega dokumenta, ki služi za pregled profesorja. Posledično so tisti, ki so dojeli pisanje in pouk matematike kot en sam prepleten proces, izrazili pozitiven odnos do uporabe pisanja pri matematičnih učnih urah. Tako pa ni bilo pri tistih, ki so pisanje in pouk matematike videli kot dva ločena procesa. Predlogi za program izobraževanja učiteljev so podani na koncu članka.

Ključne besede: stališča, prepričanja, metakognicija, reševanje problemov, prihodnji učitelji matematike, pisanje pri matematiki 


\section{Introduction}

Students often ask: What does writing have to do with mathematics? They are not open to the idea of writing in mathematics and very often view writing only as a part of language and social studies classes. On the other hand, educational organisations and researchers advocate using writing in mathematics. In its report An Agenda for Action, the National Council of Teachers of Mathematics ([NCTM], 1980) strongly recommended that the process of writing in mathematics become an integral part of mathematics lessons. In their view, "writing as a process [that] emphasizes brainstorming, clarifying, and revising ... can readily be applied to solving a mathematical problem" (p. 142). Later, they added that "writing in mathematics can also help students consolidate their thinking because it requires them to reflect on their work and clarify their thoughts about the ideas" (200o, p. 61). Hence, they considered writing to be a method or tool to both learn and communicate mathematics. Since 1989, psychologists and researchers (e.g., Brown, 1987; Cross, 2009; Pugalee, 2001; Sfard, 2001; Vygotksy, 1987) have studied the use of writing in the mathematics classroom, reporting its positive benefits for the problem solver: it promotes the development of metacognitive behaviours, it helps to construct meaning and to organise one's ideas into a new structure of ideas, and so on. Nevertheless, writing has not found a place in the mathematics classroom, especially at secondary level. In order to create a more positive writing climate in school, dissemination at the tertiary level, and/or directly in schools, is of great importance.

The present article focuses on work on writing in mathematics with prospective secondary mathematics teachers in the middle of their studies, which is the optimal time for innovation. The prospective teachers are confronted with didactical ideas that may be quite different from what they have experienced thus far, and through such conflict can examine the benefits that writing brings, as well as examining their beliefs about teaching mathematics.

\section{Theoretical considerations about writing with respect to problem solving, metacognition and beliefs, and research questions}

\section{Writing in mathematics}

Underachievement in mathematics has led to several education reforms that place the focus on instruction methods fostering higher-order thinking, such as flexible and critical thinking, and mathematical argumentation. In this regard, numerous studies (e.g., Komorek, 2009; Kramarski, Mevarech, 
\& Arami, 2002; Kuzle, 2011, 2013; Lester, 1994; Mayer, 1998; Schoenfeld, 1987, 1992; Silver, 1987) have reported that improvement in problem-solving abilities is dependent on mathematical knowledge as well as cognitive and metacognitive abilities. Hence, mathematics instruction calls for methods that support students' acquisition and development of these processes. Writing has been recognised as one possible method to do so.

One of the earliest reports on writing in mathematics came from Geeslin (1977), who stressed that students of all ages need to write about mathematics for two reasons: "as a diagnostic tool for the teacher and as a learning device for the student” (p. 113). This would then help students develop a more precise idea of mathematical concepts, as well as helping prospective teachers learn how to explain mathematics. In a report of the College Entrance Examination Board (1983) published a few years later, Kilpatrick also addressed the usefulness of writing in gaining a better understanding of mathematics and constructing individual knowledge, which influenced subsequent NCTM's reports (1989, 2000). For Countryman (1992), mathematics learning occurs when "students construct it for themselves. They can only do that by exploring, justifying, representing, discussing, using, describing, investigating, predicting, in short by being active in the world. Writing is an ideal activity for such processes" (p. 2). Writing in the mathematics classroom ranges from informal, unstructured journal writing (concept development) to formal assessments of mathematical reasoning (portfolios, homework) (e.g., Bruder \& Collet, 2011; Komorek, 2009). However, writing is not an easy process, but takes time and deep consideration from the writer: "a writer in the act of discovery is hard at work searching memory, forming concepts, and forging a new structure of ideas" (Flower \& Hayes, 2009, p. 467).

\section{Writing and metacognition}

Metacognition in problem solving is considered to be a "driving force" that influences cognitive behaviour at all stages of problem solving (Lester, 1994). Mathematical instruction that focuses on the metacognitive aspects of mathematical thinking is therefore important. Various methods aid and support the development of this higher-order thinking, one of them being writing (e.g., Brown, 1987; Bruder \& Collet, 2011; Bereiter \& Scardamalia, 1987; Cross, 2009; Kuzle, 2011, 2013; Pugalee, 2001; Sfard, 2001). From a psychological perspective, writing is planned and conscious, and is therefore a valuable method of reflecting on, consolidating and strengthening what one knows. Pugalee (2001), for instance, concluded that writing serves as a monitoring tool that allows students to record what they know, orchestrate the mathematical resources 
and decide on a problem-solving path. Moreover, it sustains the development of mental reasoning, the ability to make connections and communication skills, ultimately contributing to the enhancement of metacognitive processes. Cross (2009) confirmed that writing activities help to develop a deeper conceptual understanding of students' current knowledge, while at the same time serving as heuristics. In other words, writing is a communication tool that allows students to transmit their mathematical ideas, while enabling teachers to model their students' mathematics. However, Cross also concluded that writing is a challenging cognitive process that requires a careful examination of the thinking one wants to articulate.

\section{Beliefs about the nature of mathematics and teaching mathematics}

In his work, Ernest $(1989,1991)$ defined three types of beliefs about the nature of mathematics and described how these provide a basis for teachers' conceptions of mathematics teaching and learning: (1) the instrumentalist view, (2) the Platonist view, and (3) the problem-solving view. According to the instrumentalist view, mathematics is "an accumulation of acts, rules and skills to be used in the pursuance of some external end" (p. 250). Hence, mathematics is viewed as a finished product, whereby the teacher takes the role of an instructor and learning is viewed as "skills mastery with correct performance" (p. 250). The student, on the other hand, is a passive receiver and consumer of knowledge and skills that must be mastered by practising on routine problems. The Platonist view is also a product-oriented perspective. Mathematics is viewed as "a static but unified body of certain knowledge" (p. 250). Moreover, mathematics is discovered, not created. In other words, mathematics is perceived as a consistent, connected and objective structure. A teacher with Platonist views takes the role of an explainer, whereby learning is conceived as the reception of knowledge. However, a Platonist teacher emphasises the conceptual understanding of unified knowledge. The problem-solving view of mathematics has a more process-oriented perspective. Mathematics is seen as a "dynamically organized structure located in a social and cultural context" (p. 250). Thus, mathematics is not a finished product, but rather includes activities such as generating ideas and solving problems, as well as communicating ideas and solutions. Through these activities, mathematics is a result of human inquiry and creation. The teacher takes the role of a facilitator; in his/her classroom, learning is an active process of construction of understanding, also by the means of problem posing and problem solving. The student is an active participant in the learning process and a creator of mathematical understanding and knowledge, communicating and sharing his/her mathematics results and discussing them 
with peers. This taxonomy of beliefs was used as a theoretical framework for the present study, both as a measurement instrument and to analyse prospective mathematics teachers' views on mathematics, teaching and problem solving.

Teachers' personal beliefs and theories about mathematics, learners and learning, teaching, subjects or curriculum, learning to teach, and about the self are widely considered to play a significant role in teaching practices (Pajares, 1992; Thompson, 1992; Wilson \& Cooney, 2002). Confronting and changing prospective teachers' beliefs about mathematics and teaching has been promoted by some researchers (Cooney, 1999; Llinares, 2002) as one of the many goals of teacher preparation. Liljedahl, Rolka, and Rösken (2007), Conney (1999) and others have asserted that teacher education programmes are capable of helping to remedy the preconceived beliefs of preservice teachers. Emphasising the culture of a continuous process of personal reflection in education courses, teachers can become aware of their beliefs, theories or philosophies, so that they come to understand their own implicit theories and the ways these theories influence their professional practice (deFreitas, 2008). Teachers can then re-evaluate their beliefs and gradually replace existing beliefs with more relevant beliefs (Nespor, in Thompson, 1992). However, in order for this re-evaluation of beliefs to occur, teachers have to experience innovation for themselves, otherwise innovation lacks resonance. Given that writing is a reflective activity, it may help preservice teachers to become aware of their beliefs about it and to reflect on its effect with respect to learning, ultimately shaping their teaching practices.

Porter and Masingila (2001) gave an overview of the vast research conducted on writing in mathematics as a valuable tool for student learning in the mathematics classroom. Despite the calls of numerous research organisations and researchers, however, many mathematics teachers remain reluctant to use writing in their lessons, thus creating a gap between research and the realities of practice. As summarised in the previous section, this disconnection may lie in the fundamental belief that the process of writing is removed from the process of mathematical problem solving. If writing is to become standard in the mathematics classroom, as has been advocated for the last three decades, it is our role as mathematics educators to move teachers towards a view of mathematics and writing as a deeply related and intertwined process, rather than as two disjointed products. In order to achieve this, however, it is crucial to first understand how teachers respond to writing when doing mathematics. Miller and Hunt (1994) suggested that engagement in writing had the power to initiate change, as the actors reflect on its process.

The research on writing in mathematics lacks structured research focusing on prospective teachers' experiences with writing in mathematics and how 
such experiences might shape their attitudes towards incorporating writing in their lessons, from the standpoint of both a learner and a teacher. With these considerations in mind, a cohort of prospective secondary mathematics teachers had an opportunity to experience writing in a problem-solving seminar through exploring various mathematical problems, preparing written reports on the problem-solving process, and reflecting on it from the perspective of both a problem solver and a practitioner. Three questions were of interest for the current study:

- What metacognitive behaviours, if any, are supported by prospective secondary mathematics teachers writing reports?

- How do prospective secondary mathematics teachers react to writing mathematics during problem solving and to reflective writing after problem solving?

- What are prospective secondary mathematics teachers' perspectives on using writing with respect to problem solving in their mathematics classrooms?

\section{Methodology}

\section{Context and participants}

This was an exploratory qualitative study conducted in the problemsolving seminar Problem Solving in Mathematics, held at a large state university in Germany. The seminar took place once per week for 90 minutes, and was organised by both the author of this paper and the students. The seminar concentrated on learning about problem solving (e.g., problem-solving models, heuristics, self-regulated problem solving, teaching problem solving, problem solving with technology) facilitated through student presentations, while at the same time focusing on solving mathematics problems and how problemsolving activities can be implemented in mathematics instruction led by the instructor. The aim of the seminar was to provide the participants with a deeper understanding of problem solving through self-study, inquiry, investigation and exploration.

A cohort of 24 students in their third to sixth semester participated in the study, 13 of whom were elementary preservice teachers (Grades 1-4) and 11 of whom were lower secondary preservice teachers (Grades 5-10). Their own school memories of the mathematics classroom portrayed a traditional classroom in which learning materials and algorithms were presented by the teacher, followed by drill and practice. Very few had experience with problem solving, and those who did associated problem solving with solving puzzles, 
modelling and word problems. Thus, the participants had limited practical experience with both the theoretical and practical aspects of problem solving.

\section{Data Collection}

Data collection methods included a survey and various written materials. At the beginning of the semester, the participants completed a VAMS survey (adapted from Carlson, 1997) based on a contrasting alternative design developed by Halloun and Hestens (1996), which was used to examine participants' beliefs about mathematics as well as problem solving and its teaching. During the semester, various written instruments were administered. Every 3-4 weeks, the author of the paper administered the students' homework with 1-3 mathematical problems. The students were asked to keep a booklet comprising a problem-solving protocol and a post-reflection protocol about problem solving to allow for active engagement in knowledge construction. The problemsolving protocol served as an instrument to help students structure and guide their own problem-solving process. It was divided into four sections: the goal of the problem, the plan(s) to solve the problem, the implementation of the devised plan(s), and the conclusion(s) with respect to the problem. The students were encouraged to write down all of the ideas and questions that arose during the problem-solving process. After solving the problem, they had to reflect on the experience of writing guided by several questions in the post-reflection protocol. At the end of the semester, the students submitted nine booklets in the form of a portfolio. In addition, they had to write 1-2 page reflection papers designed to encourage them to relate what they were learning in class to their own practice or experience. In particular, they had to reflect on the semesterlong experience of writing mathematics, both through the eyes of a student and a future practitioner, and report on aspirations for implementing writing when undertaking problem solving in their own mathematics classrooms.

\section{Data analysis}

Data analysis of both the quantitative and qualitative data went through several stages, as suggested by Yoo (2008) and Patton (2002), respectively. The data analysis began by administering the VAMS survey to a community of mathematicians and mathematics educators. The survey consisted of 50 items pertaining to two dimensions: epistemological (the nature of mathematics, connections and problem solving) and pedagogical (the learnability of mathematics and problem solving, and the personal relevance of mathematics and problem solving). Each item consisted of a statement followed by two contrasting alternative views. The participants were asked to identify their level 
of agreement with the two alternatives on a scale from 1 to 8 . This contrasting alternative design increases the validity and reliability of the belief measurement (Halloun \& Hestenes, 1996; Philipp, 2007), allowing the researcher to distinguish between the product view (instrumentalist), the mixed view (Platonist view), and the problem-solving view (process) of mathematics and its teaching, as suggested by Carlson (1997) and Yoo (2008). Based on the experts' answers, student answers were scored on a scale from o to 2 . Hence, the maximum total score for the 50 survey items was 100 points. The student's response to the VAMS item was considered ideal if it fell into the first category, which contained a high frequency of mathematicians' responses. It was considered mixed if it fell into the second category, which contained a low frequency of mathematicians' responses, and it was considered non-ideal if it fell into the third category, which contained zero or a very low number of mathematicians' responses. Students who achieved less than 55 points were designated as having a product or instrumentalist view, those scoring between 55 and 79 points were considered to have a mixed or Platonist view, and those scoring from 80 to 100 points were deemed to have a process or problem-solving view. Out of the 24 students, 5 were assigned a product view of mathematics, 16 a mixed view and 3 a process view.

After completing the quantitative data analysis, the qualitative data analysis commenced. Given that the examination of beliefs is rather complex, field notes containing data from the seminar actions and conversations were balanced against the survey results. This enabled the confirmation or repudiation of the data, as well as the refinement of the characterisation of participants' beliefs, as suggested by Philipp (2007). Hence, both the quantitative and qualitative data allowed the identification of the three types of participants based on their views. In the second step, each of the participants' booklets was read and their responses were analysed based on the three research questions. The analytical inductive method (Patton, 2002) was used for the data for convergence, whereby analysis of the data is first deductive and then inductive. The deductive analysis was coded and analysed based on the theoretical framework, which was then refined using inductive analysis through emerging themes and additional codes. The categories of codes were used to interpret and understand data for a more in-depth discussion according to the theme. After the analysis of the booklets was complete, the final reflection paper described above was analysed using textual analysis (Patton, 2002). 


\section{Results}

This section presents the results of the study with respect to the research questions. The first section focuses on metacognitive behaviours supported by writing, the next section contains a report on the participants' experiences with respect to writing, and the third and final section focuses on the participants' attitudes and beliefs about using writing in their future classrooms. In order to allow a richer description of the phenomenon, four cases are examined. The four participants - Chloe, Hannah, James and Leonard - were chosen randomly within their belief category.

\section{Participants' backgrounds and belief structure}

Leonard achieved 80 points in the survey and was therefore labelled as a process-oriented type. He was in his sixth semester of a teacher education programme for Hauptschule, Realschule and Gesamtschule. ${ }^{2}$ For him, mathematics was mainly a dynamic and continuously growing field in which humans create their own knowledge. The role of a teacher was more that of a facilitator guiding students to construct mathematical knowledge and understanding it on their own, rather than that of a transmitter. He viewed learning as an active process in which students participate in the learning activity in order to work out and discuss the solution with others. For Leonard, solving problems was mostly an enjoyable experience that allowed the development of his reasoning skills. He believed that a good problem solver primarily needs to think flexibly, but is facilitated to a large extent by resources, skills and strategies rather than persistence.

Hannah achieved 69 points and was therefore labelled as a mixed type. She was in the third semester of a teacher education programme for primary school. For her, mathematics was a static but unified body of knowledge, perceived more as a formal than a creative representation of the real world. Hence, doing mathematics was more like following a recipe than an individual's creative way of explaining the world around him/her. For Hannah, the teacher had the role of a mediator, while emphasising conceptual understanding. Solving problems was both an enjoyable and a frustrating experience for her, but she noted that it helped to develop her reasoning skills. She believed that a good problem solver primarily needs to think flexibly, but is aided more by resources, skills and strategies than persistence.

James achieved 67 points and was therefore labelled as a mixed type. He was in his fifth semester of a teacher education programme for Hauptschule, Realschule and Gesamtschule. For him, mathematics was a static but unified

2 Hauptschule, Realschule and Gesamtschule are types of secondary school in Germany. 
body of knowledge, perceived as a more creative representation of the real world rather than formalisation. Doing mathematics was much like following a recipe, and the result was a piece of artwork. The goal of instruction, for him, was to transmit knowledge, while at the same time guiding students to understand the transmitted material. Solving problems was more an enjoyable experience than a frustrating one, and was more dependent on his resources than on perseverance. James believed that a good problem solver needed only to think flexibly and know how and when to apply various types of reasoning and skills.

Chloe achieved 45 points and was therefore labelled as an absolutist type. She was in her fifth semester of a teacher education programme for primary school. For her, mathematics was primarily a formal way of representing the real world. She held mathematics to be a static body of facts independent of human invention. The role of the teacher was that of a transmitter of knowledge, with students absorbing mathematical concepts and practising routine problems for accurate performance rather than actively participating in the learning process. For Chloe, solving mathematical problems was both an enjoyable and frustrating experience, but she recognised that it helped to develop her reasoning skills. For her, an organised memory (formulas, procedures), flexible thinking and perseverance were the characteristics of a good problem solver.

\section{Metacognitive activities supported by the writing process}

Throughout the booklets, the participants demonstrated reasoning that included not only cognitive behaviours, but also metacognitive behaviours. The use of a problem-solving protocol as an instrument to analyse metacognitive behaviours was somewhat limited as the participants did not write a narrative of their problem-solving processes. However, in combination with the post-reflection protocol, it allowed an examination of which metacognitive behaviours were prompted through the writing process. Writing supported various metacognitive processes. For instance, Leonard most often reported that through writing he was able to organise his thinking: he drew a sketch of the problem and noted possible problem-solving approaches before he decided on the final problem-solving approach. Hence, writing enabled him to manage the various resources he possessed (knowledge, strategies) and to regulate his problemsolving processes in a productive way. In addition, by writing down his ideas, he was able to control the reasonableness of his arguments and thus the correctness of his problem solution. Through writing, he was therefore able to explore the problem-solving space before arriving at a solution.

Hannah added that writing helped "to consciously think about problemsolving processes from a metacognitive perspective". That is, in having to state 
the problem goal, she focused on understanding the problem before choosing a perspective to solve the problem; before choosing a perspective, she wrote down possible solution paths based on her knowledge, and then evaluated the plausibility of each approach before deciding on one. Lastly, after she had carried out the plan, she read through her arguments again before writing down the solution. Hence, she monitored, regulated and evaluated her work continuously. However, such behaviour was only present when she knew how she might solve the problem.

James initially found it difficult to provide clear goals and adequate explanations of his work, and to use proper mathematical language to communicate his problem-solving process clearly. Nevertheless, as the semester progressed, this picture changed and growth in metacognitive activities occurred. Instead of merely writing the solution steps, he started using writing for exploration: he gathered strategies and accessed mathematical content that might be useful for the problem before choosing a problem-solving path. When the plan did not work out, he was able to look back and decide on another perspective. Thus, writing helped him to systematically gather relevant information, to organise his thoughts, to regulate the available resources, and to refine them when evaluation was lacking. Redirection and reorganising thinking in productive directions were supported by the writing process. For Leonard, Hannah and James, writing thus generated an awareness of their thinking and helped them to develop a deeper conceptual understanding of their current knowledge, to analyse the current problem-solving state, and to move towards identifying a successful solution plan. Sfard (2001) described this as a dialogical endeavour, whereby we inform ourselves, we argue, we ask questions and we wait for our responses (pp. 4-5). As a result of such dialogic endeavour, the students were able to construct new knowledge through the interaction between their problem-solving space and their writing space, in order to meet specific goals.

Chloe's booklet, on the other hand, did not exhibit any evidence of metacognitive behaviour; she completely neglected exploration and arrived directly at the problem solution, adding in the post-reflection guide that the writing protocol only helped her to structure her work in four sections. Such behaviour was consistent with her absolutist view of mathematics, in which mathematics is detached from exploration and individual creation.

\section{Writing to reflect on problem solving}

During the semester, the participants experienced writing in a problemsolving seminar through exploring different mathematical problems, preparing written reports of the problem-solving process, and reflecting on it through the 
perspective both as a problem solver and a practitioner. However, the participants responded differently to completing the protocols. Some found it helpful immediately, some after some time, and others not at all. Some found it helpful only with respect to a specific problem in which the method helped them to organise their thoughts. Leonard completed each protocol, offering rich descriptions of his reflection. Through writing, he realised how difficult it is to note down what one is thinking in a comprehendible manner, but added that describing his processes "helped [him] go back, follow his train of thought and check the reasonableness of his solution", as well as to check whether his arguments were correct. He also added that it helped him check whether "another person reading the problem-solving path could arrive at the solution as well". The process of writing helped him to "intensively engage in problem solving", "put down his ideas immediately", "revise work" and "structure his approach". The problemsolving protocol prompted metacognitive behaviours - such as planning, monitoring, regulation and evaluation - which were beneficial for his work.

Hannah added that having a protocol helped her to structure her work by preventing it from becoming chaotic. In addition, she "put the solution in the background and focused on the process". However, when she was unable to solve a problem, she left the problem-solving protocol empty, writing in the post-reflection protocol that the problem-solving protocol was not always helpful. In their final paper, Leonard and Hannah added that the post-reflection guide prompted them to go over their problem-solving protocol and re-examine the quality of their work and of the problem-solving process. In addition, they believed that protocols would allow them to assess their students' thinking and possible knowledge deficits.

James's attitude towards writing changed positively as the semester progressed. James, like Leonard and Hannah, stated that preparing the problemsolving protocol helped him to consciously organise his thoughts. All three felt that writing could help them better understand their thinking processes and remember key ideas of the problem-solving process, which they could then use in future problem solving. Writing allowed participants "to look back at their thoughts and reflect on their growth", as noted previously in the literature (Flores \& Brittain, 2003, p. 114) and as observed in Leonard, Hannah and James. It was, however, clear that as the semester progressed their post-reflection became repetitive. Leonard wrote in his final paper "at the beginning it was very helpful to write everything down, to reflect on the experience ... but afterwards it become boring to explain the same things over and over again". As time passed, Chloe found little use for either the problem-solving or the postreflection protocol, stating that they were time consuming and that she did not 
see the point in describing her problem-solving processes and reflecting on the writing down of her problem-solving process. For her, writing was extremely removed from exploring mathematics. In contrast to the other participants, she said that preparing booklets did not help her to organise ideas.

\section{Beliefs about writing from a practitioner's perspective}

Participants established the connection between problem solving and mathematics from a practitioner's perspective with varying intensity. Both Leonard and Hannah indicated that they found preparing booklets very helpful and articulated a rather strong belief that writing should be incorporated in regular mathematics lessons. For both of them, writing was an instrumental part of problem-solving activity, and therefore an important part of the mathematics classroom, enabling students to consolidate of their knowledge and supporting the development of conceptual understanding. Leonard noted that, from a learner's perspective, he was able to discern benefits of writing for his students, "I was able to systematically structure my work and intensively engage in thinking what the next step should be. My students could benefit from writing as well". He added that it could help students to "learn how to justify their thinking and support their individual problem-solving process", while at the same time enabling him to "understand [his] students' thinking and gaps in knowledge" they might have.

From the start, Hannah was open to writing, although she was not initially sure how mathematics and writing related to each other. However, as the semester progressed, her problem-solving and post-reflection protocols changed in their nature and quality. She was willing to explore connections between writing and problem solving. By doing so, her mixed views tended to give way to new conceptual views, enabling positive beliefs and attitudes towards writing and doing mathematics. Hence, this experience and her reflection on it allowed her to connect the writing process to building conceptual understanding and constructing new knowledge. In her final paper, she wrote, "by writing, students can actively experience problem solving as a mathematician does and construct new knowledge. They can explain thinking in their own words". She stated she would use writing in her classroom, adding that we should "add prompts within problem-solving protocols to help the student overcome barriers", as she found that the protocol was not helpful when she was stuck. Last but not least, she reported that she would use booklets as resources in her classroom.

James, on the other hand, much like Hannah, held that teachers should promote conceptual understanding, but was somewhat confused about the role of writing in the mathematics class. Many questions remained open for him: 
"Writing helped me organise my thoughts and helped go on the right path. But it was time consuming. It will be overwhelming to teach what needs to be taught, prepare students for exams, and on top of it use writing." He added, "I am not sure how often I should use booklets. I do not feel ready to use writing in my classroom." Hence, the participants who were aware of their writing and learning through writing seemed to benefit most from the overall process, and were thus more likely to use writing in their own classrooms. It seems that direct instruction in writing is needed for teachers to feel competent to use writing in their lessons.

Unlike the other participants, Chloe held to a product view of mathematics and tended towards a traditional classroom rather than a studentoriented classroom. She indicated that preparing booklets was extremely time consuming and after the second booklet the quality of her work dropped. She viewed writing as a process disconnected from problem solving and merely as a means to produce a formal document to be evaluated by the instructor. She summarised her thoughts: "Writing is useful, but it does not belong in a mathematics class. When students write, they focus on writing and not on the mathematics. For me, it is important that students can follow procedures I give them, and to do so they do not need writing protocols." Hence, it seems that not only beliefs about mathematics influence whether teachers use writing in their classroom, but also their beliefs about writing in mathematics.

\section{Conclusions and final thoughts}

Mathematics is more than just numbers. Writing is a challenging cognitive process that requires a careful examination of the thinking one wants to articulate (Bereiter \& Scardamalia, 1987; Flower \& Hayes, 1980). In this project, the students were asked to solve various mathematical problems based on their knowledge and report on this experience. In order to do so effectively, the participants needed to engage in various metacognitive processes: to orient themselves with respect to the problem, to decide on a strategy to solve the problem based on the vast resources they possessed, to monitor and regulate their processes, and to evaluate the reasonableness of their planned processes and/or of the solution (Kuzle, 2011, 2013; Pugalee, 2001). This was, however, not an easy task; issues of providing clear goals, of adequate explanations of their thinking, and of the integration of mathematics and words sometimes interfered with their ability to effectively communicate the mathematics.

The quality of writing differed. For instance, while Chloe just reported what she already knew, Hannah, James, and Leonard were able to construct new knowledge through the interaction between their problem-solving space 
and their writing space in order to meet specific goals, as suggested by Vygotsky (1978). Hence, much like verbal communication (Cross, 2009), the act of producing convincing arguments through writing created an additional cognitive demand on the participant. This ability to "efficiently generate adequate content so that one has the flexibility to select from what is available and discard what is deemed unnecessary or irrelevant (a skill of more expert writers) appears to be one's knowledge of the subject being written about and the ability to readily access this knowledge" (Cross, 2009, p. 925). The participants who were aware of their writing and learning through the process of writing seemed to benefit most from the overall process, making them most likely to use writing in their own classroom. However, it seems that beliefs about writing also play a significant role, as James and especially Chloe were not convinced to use writing in their classrooms.

The communication principle is one of the standards outlined in the mathematics curriculum (NCTM, 2000). As one of the communication methods, writing is implemented in mathematics classrooms with varying intensity, despite its benefits (e.g., Bereiter \& Scardamalia, 1987; Cross, 2009; Pugalee, 2001; Sfard, 2001). This may be a result of a misconception that the process of writing and that of doing mathematics are unrelated. With respect to Hannah and Leonard, the results of the present study showed that when writing helped support the metacognitive processes essential for productive problem solving, the distinction between the two disappeared. Thus, although beliefs are extremely difficult to change (Pajares, 1992), rich and meaningful experiences may help promote awareness of the benefits of writing in mathematics, and encourage the development of positive beliefs with regard to the process of writing and mathematics, as suggested by Miller and Hunt (1994).

Mathematics educators cannot assume that student teachers come with experience and knowledge of how to write effective mathematical explanations. They need experience in writing in order to build awareness of the merits of writing with respect to promoting mathematical understanding. Moreover, they need direct instruction in what it means to target an audience, to state the goal in a well-defined introduction, to link and explain representations, and to properly integrate mathematical notation and figures with words. If writing is to become an accepted method for both teaching and learning mathematics, teachers need to experience high quality writing for themselves, to raise awareness of its benefits, and to be trained in how to use writing in their classroom, as demonstrated by both Hannah and Leonard. Moreover, both processes need to transform into a single process. Only then will teachers use writing as a method of critical thinking that can help students learn how to think mathematically. 


\section{References}

Bereiter, C., \& Scardamalia, M. (1987). The psychology of written composition. Hillsdale, NJ: Erlbaum. Brown, A. (1987). Metacognition, executive control, self-regulation and other more mysterious mechanisms. In F. Weinert \& R. Klume (Eds.), Metacognition, motivation and understanding (pp. 65-116). Mahwah, NJ: Erlbaum.

Bruder, R., \& Collet, C. (2011). Problemlösen lernen im Mathematikunterricht. Berlin: Cornelsen. Carlson, M. P. (1999). The mathematical behavior of six successful mathematics graduate students: Influences leading to mathematical success. Educational Studies in Mathematics, 40(3), 237-258. College Entrance Examination Board. (1983). Academic preparation for college: What students need to know and be able to do. New York: Author.

Cooney, T. J. (1999). Conceptualizing teachers' ways of knowing. Educational Studies in Mathematics, $38,163-187$.

Countryman, J. (1992). Writing to learn mathematics. Portsmouth, NH: Heinemann.

Cross, D. I. (2009). Creating optimal mathematics learning environments: Combining argumentation and writing to enhance achievement. International Journal of Science and Mathematics Education, 7(5), 905-930.

deFreitas, E. (2008). Troubling teacher identity: Preparing mathematics teachers to teach for diversity. Teaching Education, 19(1), 43-55.

Ernest, P. (1989). Philosophy, mathematics and education: The state of the art. International Journal of Mathematics Education in Science and Technology, 20, 555-559.

Ernest, P. (1991). The philosophy of mathematics education. Abingdon, Oxon, UK: Routledge Farmer. Flores, A., \& Brittain, C. (2003). Writing to reflect in a mathematics methods course. Teaching Children Mathematics, 10, 112-118.

Flower, L., \& Hayes, J. R. (2009). The cognition of discovery: Defining a rhetorical problem. In S. Miller (Ed.), The Norton book of composition studies (pp. 467-478). New York: W.W. Norton.

Geeslin, W. E. (1977). Using writing about mathematics as a teaching technique. Mathematics Teacher, $70,112-115$.

Halloun, I., \& Hestenes, D. (1996). Views About Sciences Survey: VASS. Paper presented at the annual meeting of the National Association of Research in Science Teaching, St. Louis, MO. (ERIC Document Reproduction Service No. ED394840).

Komorek, E. (2009). Mit Hausaufgaben Problemlösen und eigenverantwortliches Lernen in der Sekundarstufe I fördern. Entwicklung und Evaluation eines Ausbildungsprogramms für Mathematiklehrkräfte. Berlin: Logos Verlag.

Kramarski, B., Mevarech, Z. R., \& Arami, M. (2002). The effects of metacognitive instruction on solving mathematical authentic tasks. Educational Studies in Mathematics, 48, 225-250.

Kuzle, A. (2011). Preservice teachers' patters of metacognitive behavior during mathematics problem solving in a dynamic geometry environment. Doctoral dissertation. The University of Georgia-Athens. Kuzle, A. (2013). Patterns of metacognitive behavior during mathematics problem-solving in a 
dynamic geometry environment. International Electronic Journal of Mathematics Education, 8(1), $20-40$.

Lester, F. K. (1994). Musing about mathematical problem-solving research: 1970-1994. Journal for Research in Mathematics Education, 25(6), 660-675.

Liljedahl, P., Rolka, K., \& Rösken, B. (2007b). Affecting affect: The reeducation of preservice teachers' beliefs about mathematics and mathematics teaching and learning. In W. G. Martin, M. E. Strutchens, \& P. C. Elliott (Eds.), The learning of mathematics (pp. 319-330). Reston, VA: National Council of Teachers of Mathematics.

Llinares, S. (2002). Participation and reification in learning to teach: The role of knowledge and beliefs. In G. C. Leder, E. Pehkonen, \& G. Törner (Eds.), Beliefs: A hidden variable in mathematics education? (pp. 195-209). Dordrecht, The Netherlands: Kluwer.

Mayer, R. E. (1998). Cognitive, metacognitive, and motivational aspects of problem solving. Instructional Science, 26(1-2), 49-63.

Miller, L. D., \& Hunt, N. P. (1994). Professional development through action research. In D. B.

Aichele \& A. F. Coxford (Eds.), Professional development for teachers of mathematics (pp. 296-303).

Reston, Va: The National Council of Teachers of Mathematics.

National Council of Teachers of Mathematics. (1980). An agenda for action: Recommendations for school mathematics of the 1980s. Reston, VA: Author.

National Council of Teachers of Mathematics. (2000). Principles and standards for school mathematics. Reston, VA: Author.

Pajares, F. (1992). Teachers' beliefs and educational research: Cleaning up a messy construct. Review of Educational Research, 62(3), 307-332.

Patton, M. Q. (2002). Qualitative research and evaluation methods. Thousand Oaks, CA: Sage.

Philipp, R. A. (2007). Mathematics teachers' beliefs and affect. In F. K. Lester (Ed.), Second handbook of research on mathematics teaching and learning, Vol. 2 (pp. 257-315). Charlotte, NC: Information Age.

Porter, M., \& Masingila, J. (2001). Examining the effects of writing on conceptual and procedural knowledge in calculus. Educational Studies in Mathematics, 42(2), 165-177.

Pugalee, D. K. (2001). Writing, mathematics, and metacognition: Looking for connections through students' work in mathematical problem solving. School Science and Mathematics, 101(5), 236-245. Schoenfeld, A. H. (1987). What's all the fuss about metacognition? In A. H. Schoenfeld (Ed.), Cognitive science and mathematics education (pp. 189-215). Hillsdale, NJ: Erlbaum.

Schoenfeld, A. H. (1992). Learning to think mathematically: Problem solving, metacognition, and sense-making in mathematics. In D. Grouws (Ed.), Handbook of research on mathematics teaching and learning (pp. 334-370). New York: Macmillan.

Sfard, A. (2001). Learning mathematics as developing a discourse. In R. Speiser, C. Maher, \& C. Walter (Eds.), Proceedings of the Twenty-first Conference of PME-NA (pp. 23-44). Columbus, OH: ERIC Clearing House for Science, Mathematics, and Environmental Education.

Silver, E. A. (1987). Foundations of cognitive theory and research for mathematics problem-solving 
instruction. In A. Schoenfeld (Ed.), Cognitive science and mathematics education (pp. 33-6o.)

Hillsdale, NJ: Erlbaum.

Thompson, A. (1992). Teacher's beliefs and conceptions: A synthesis of the research. In D. A.

Grouws (Ed.), Handbook of research on mathematics teaching and learning (pp. 127-146). New York:

Macmillan.

Vygotsky, L. S. (1978). Mind in society: The development of higher psychological processes. Cambridge, MA: Harvard University Press.

Wilson, M., \& Cooney, T. J. (2002). Mathematics teacher change and development. In G. C. Leder,

E. Pehkonen, \& G. Torner (Eds.), Beliefs: A hidden variable in mathematics education? (pp. 127-147).

Dordrecht, The Netherlands: Kluwer.

Yoo, S. (2008). Effects of traditional and problem-based instruction on conceptions of proof and pedagogy in undergraduates and prospective mathematics teachers. Doctoral dissertation. The University of Texas, Austin.

\section{Biographical note}

Ana Kuzle, Dr., is a research assistant in the Institute for Mathematics at the University of Paderborn. After finishing her dissertation on preservice teachers' metacognitive processes while solving nonroutine geometry problems in a dynamic geometry environment at the University of Georgia, she moved to Paderborn and continued working in the area of problem solving with both preservice and inservice mathematics teachers. She founded DUPLO project (Durch Problemlosen Mathematik lernen), in which the main goal is that students develop understanding of mathematical concepts and methods by teaching these through problem solving. Within the project she focuses on problem solving processes and its promotion as well as beliefs towards problem solving and possibility of their change through new innovative learning and teaching methods and environments. 